\title{
The application of ADMS-Urban model to estimate nitrogen dioxide concentrations in cold and warm seasons in Kaunas city
}

\author{
Audrius Dėdelë*, \\ Auksė Miškinytė \\ Department of Environmental Sciences, \\ Vytautas Magnus University, \\ Vileikos st. 8, \\ LT-44404 Kaunas, \\ Lithuania
}

Road traffic is one of the main sources of pollution affecting air quality in urban areas which can have impacts on human health. One of the most common traffic-related pollutants is nitrogen dioxide $\left(\mathrm{NO}_{2}\right)$. Atmospheric dispersion models, such as ADMSUrban, can be used to examine emissions from many various sources (road transport, industrial, domestic) and to estimate or predict the concentration of pollutants emitted from these sources into the atmosphere.

The paper examines the performance of ADMS-Urban dispersion model to predict nitrogen dioxide concentrations from emission sources. Modelled concentrations for cold and warm seasons have been compared with measured nitrogen dioxide concentrations at 41 site in Kaunas city.

The purpose of this study was to assess the dispersion of nitrogen dioxide pollution in cold and warm seasons comparing modelled with ADMS-Urban model and measured with passive samplers $\mathrm{NO}_{2}$ concentrations in Kaunas city.

Modelled average nitrogen dioxide concentration in cold season was $21.79 \mu \mathrm{g} / \mathrm{m}^{3}$, while measured with passive samplers - $19.82 \mu \mathrm{g} / \mathrm{m}^{3}$. The air pollution was significantly higher during the cold season. Modelled and measured $\mathrm{NO}_{2}$ concentrations in warm season were 12.28 and $11.62 \mu \mathrm{g} / \mathrm{m}^{3}$, respectively. Results showed that ADMS-Urban dispersion model tends to overpredict nitrogen dioxide concentrations and this is most evident when smaller values are modelled, while modelled maximum concentrations are underestimated compared with measured $\mathrm{NO}_{2}$ values.

Key words: nitrogen dioxide, modelling, ADMS-Urban model, human health

* Corresponding author. E-mail: a.dedele@gmf.vdu.lt 


\section{INTRODUCTION}

Transport is a significant and increasing source of air pollution in many European cities as well as in Lithuania and emissions from road traffic have been the cause for concern about the effects of urban air quality on human health and environment (Colvile et al., 2001).

Air pollution emitted from exhaust motor gases, which contain about 200 different chemical substances, penetrates into all urban areas, so the air quality is largely dependent on the existing transportation system in the city (Jakimavičius et al., 2009). The quantities of emissions from road transport depend on the vehicle category, road type (urban, rural, motorway), quantity and quality of fuel, driving mode and the intensity of traffic flow. Peak concentrations of pollutants occur during morning and afternoon rush hours due to increasing volume of traffic (Zuurbier et al., 2011).

The most recent traffic-related pollutant to be implicated in causing an adverse effects on human health and urban environmental quality is nitrogen dioxide, which concentrations tend to be higher near highways, along busy roads (Bellander et al., 2001) and in city centres (Bogo et al., 2001). According to the latest report from the European Environment Agency (EEA) the lowest pollution levels of nitrogen dioxide occur at rural stations, while the highest $\mathrm{NO}_{2}$ concentrations and exceedances are observed at traffic stations (EEA, 2012).

Many epidemiological studies followed on the effects of various road traffic emissions on a range of health endpoints and revealed that increased levels of nitrogen dioxide can irritate the lungs, lower resistance to respiratory infections, increase respiratory disease (Studnicka et al., 1997) and also can be associated with asthma incidence rates among children and an increase in emergency cardiovascular hospital admissions (Ballester et al., 2001; Lee et al., 2002).

Urban air quality modelling is a useful tool to describe the relationship between emissions emitted from various sources, meteorology, topography and other factors, which have the impact on the dispersion of pollutants in the city (Daly et al., 2007).

The Gaussian type models are most commonly used in air quality modelling and are designed to determine the spatial distribution of air pollutants concentrations. These distributions depend on a variety of meteorological conditions.

Modelling of air pollutants enables the assessment of many scenarios, which depend on different traffic flows, type of vehicle, number of industrial sources and other factors included in the model as air pollution measurements give information only about a very limited situation (Silva et al., 2008).

One of the most advanced software for urban air quality assessment and management is ADMS-Urban, which can be used to examine emissions from many various sources (road transport, industrial, domestic) simultaneously and is based on the latest understanding of the boundary layer structure (CERC, 2011). ADMS-Urban model is supported for use with ArcGIS software, which allows a visualisation and manipulation of the spatial data (CERC, 2011; Owen et al., 1999).

The purpose of this study was to assess the dispersion of nitrogen dioxide pollution in cold and warm seasons comparing modelled with ADMS-Urban model and measured concentrations in Kaunas city.

\section{MATERIALS AND METHODS}

\section{The ADMS-Urban model}

ADMS-Urban is a Gaussian dispersion model developed by Cambridge Environmental Research Consultants (CERC), which can simulate air pollution in urban areas using point, line, area, volume and grid source types (CERC, 2011).

Road transport emissions were calculated from traffic flow data by using the 1999 Design Manual for Roads and Bridges (DMRB 1999) emission factor dataset. Road name, elevation of road $(\mathrm{m})$, road width $(\mathrm{m})$, canyon height $(\mathrm{m})$, road geometry $(\mathrm{x}, \mathrm{y})$, vehicle category, 
average speed $(\mathrm{km} / \mathrm{hr})$ and emissions $(\mathrm{g} / \mathrm{km} / \mathrm{s})$ were entered for each road segment. Traffic flow measurement data were obtained from directly counting the number of light and heavy duty vehicles at selected points in Kaunas city and were used to calculate vehicle count per hour.

The main industrial point sources of Kaunas city were included in the modelling and each of them has parameters of source name, type, height $(\mathrm{m})$, diameter $(\mathrm{m})$, velocity $(\mathrm{m} / \mathrm{s})$, temperature of the release $\left({ }^{\circ} \mathrm{C}\right)$ and $\mathrm{X}, \mathrm{Y}$ coordinates of the centre of the point source.

Grid source cells (a total number of 2028 grid cells) were used to define emissions from domestic heating sources, whose emissions significantly increase the total air pollution in the city during winter.

Average annual background concentration data were obtained from rural monitoring site around the city and were included in the modelling to represent pollutants transported into the modelled area for 2011.

Hourly sequential meteorological data for 2011 were used in this study and contain information about year, day, hours, surface temperature $\left({ }^{\circ} \mathrm{C}\right)$, wind speed $(\mathrm{m} / \mathrm{s})$, wind angle $\left({ }^{\circ}\right)$, cloud cover (oktas) and relative humidity (\%).
The comparison between cold (winter) and warm (summer) seasons wind roses of 2011 year datasets are shown below (Fig. 1). The wind roses show that the dominant direction of wind is from southwest in winter season, while for summer season - from southeast and northwest. High-speed winds blow from the west and southwest direction.

\section{Measuring $\mathrm{NO}_{2}$ with diffusive samplers}

$\mathrm{NO}_{2}$ concentrations were measured using Ogawa passive samplers. Sampling was carried out in 41 measurements point in Kaunas city. All Ogawa passive samplers were exhibited for 14 days. Measurements were taken in cold and warm seasons. The comparison between measured with Ogawa passive samplers and modelled with ADMS-Urban dispersion model nitrogen dioxide concentrations in cold and warm seasons was made by calculating differences.

\section{RESULTS AND DISCUSSION}

Distribution of $\mathrm{NO}_{2}$ pollution levels and passive samplers measurements sites in Kaunas city during cold and warm seasons are presented in

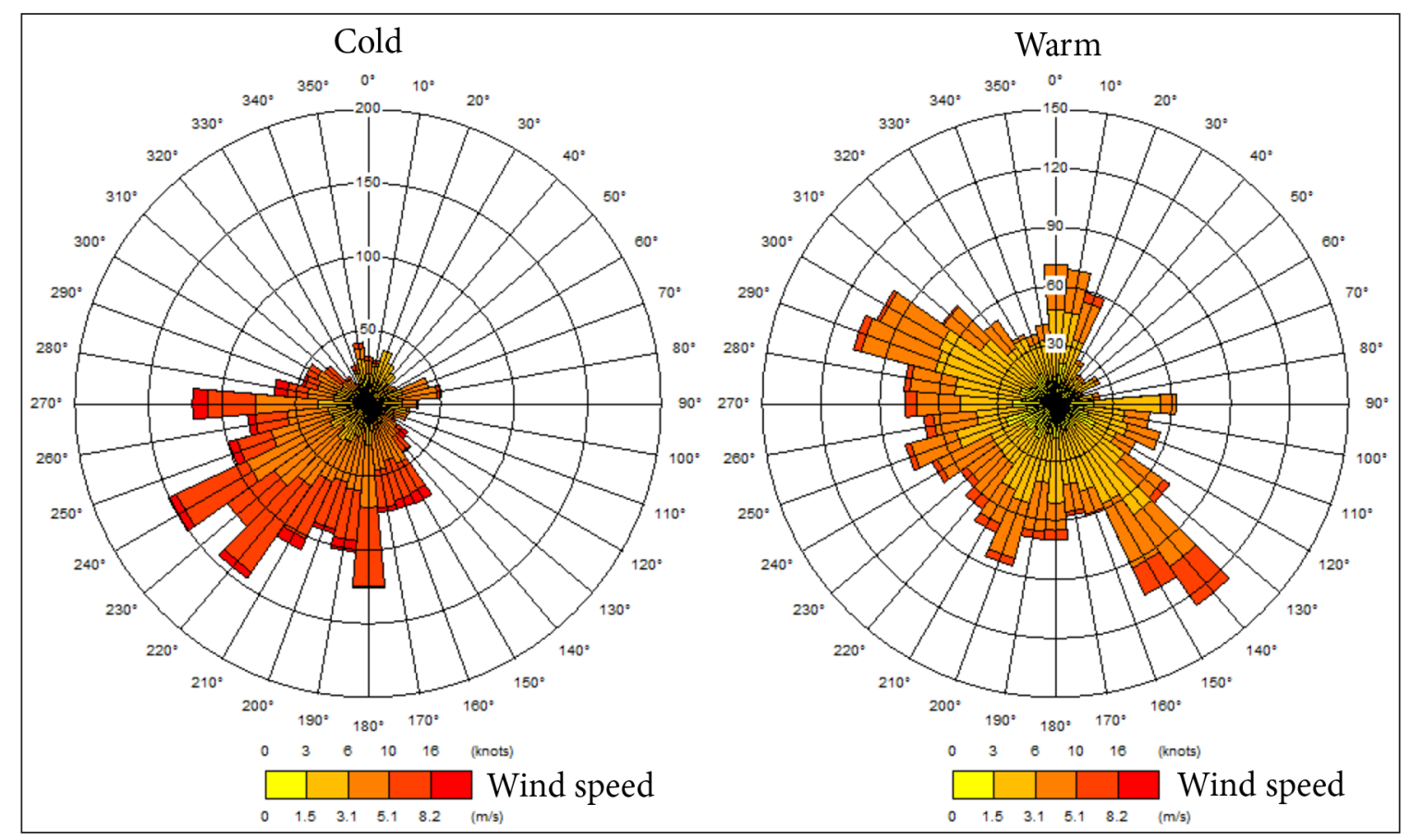

Fig. 1. Wind roses for the year 2011 from Kaunas Meteorological Station 
Fig. 1 and Fig. 2. These two layers of geographic data were combined using a geographic information system (GIS).

The highest pollution level was modelled in the central district in both studied seasons, average $\mathrm{NO}_{2}$ concentration was $27.4 \mu \mathrm{g} / \mathrm{m}^{3}$ and $18.4 \mu \mathrm{g} / \mathrm{m}^{3}$, respectively in cold and warm season. The most polluted districts were Dainava, Žaliakalnis and Vilijampolè, where $\mathrm{NO}_{2}$ concentration ranged from 24.0 to $24.8 \mu \mathrm{g} / \mathrm{m}^{3}$. The lowest $\mathrm{NO}_{2}$ concentration was found in Panemune district $-12.7 \mu \mathrm{g} / \mathrm{m}^{3}$ in cold season (Fig. 2). Modelled concentrations of nitrogen dioxide were much lower in warm season and the highest pollution level was determined near high-traffic areas and in the main streets of the city with high traffic volume (these are presented mostly in the city centre) as the road transport is the main source of urban air pollution at this time. The lowest $\mathrm{NO}_{2}$ concentration was modelled in Panemune and Aleksotas districts 6.5 and $7.3 \mu \mathrm{g} / \mathrm{m}^{3}$, respectively.
In order to validate AMDS-Urban model, average $\mathrm{NO}_{2}$ concentrations predicted by this model were compared to $\mathrm{NO}_{2}$ concentrations from Ogawa passive samplers at 41 measured site in Kaunas city during cold and warm seasons.

The comparison between measured and modelled concentrations of nitrogen dioxide is shown in Fig. 4. Average $\mathrm{NO}_{2}$ concentrations predicted by ADMS-Urban model were higher than those measured with passive diffusion samplers. Modelled average nitrogen dioxide concentration in cold season was $21.79 \mu \mathrm{g} / \mathrm{m}^{3}$, while measured with passive samplers $19.82 \mu \mathrm{g} / \mathrm{m}^{3}$ (Fig. 4). Modelled and measured $\mathrm{NO}_{2}$ concentrations in warm season were 12.28 and $11.62 \mu \mathrm{g} / \mathrm{m}^{3}$, respectively. The air pollution was significantly higher during the cold season because of the increased amounts of emissions from domestic and industrial heating. The difference between modelled and measured $\mathrm{NO}_{2}$ concentrations was $1.97 \mu \mathrm{g} / \mathrm{m}^{3}$ (9.9\%) and $0.66 \mu \mathrm{g} / \mathrm{m}^{3}(5.7 \%)$, respectively for

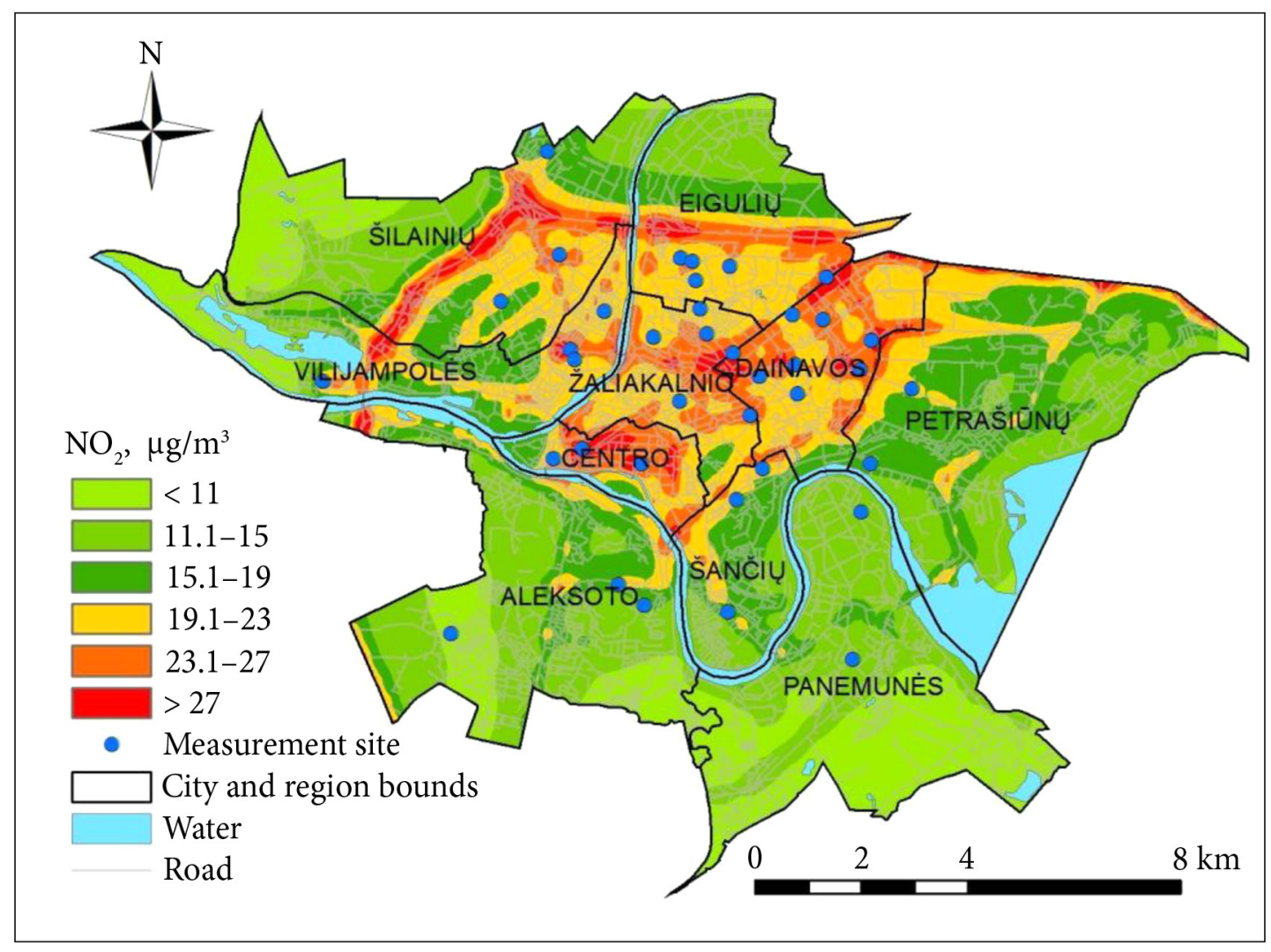

Fig. 2. Modelled nitrogen dioxide concentration $\left(\mu \mathrm{g} / \mathrm{m}^{3}\right)$ in cold season and passive samplers measurements sites in Kaunas city 


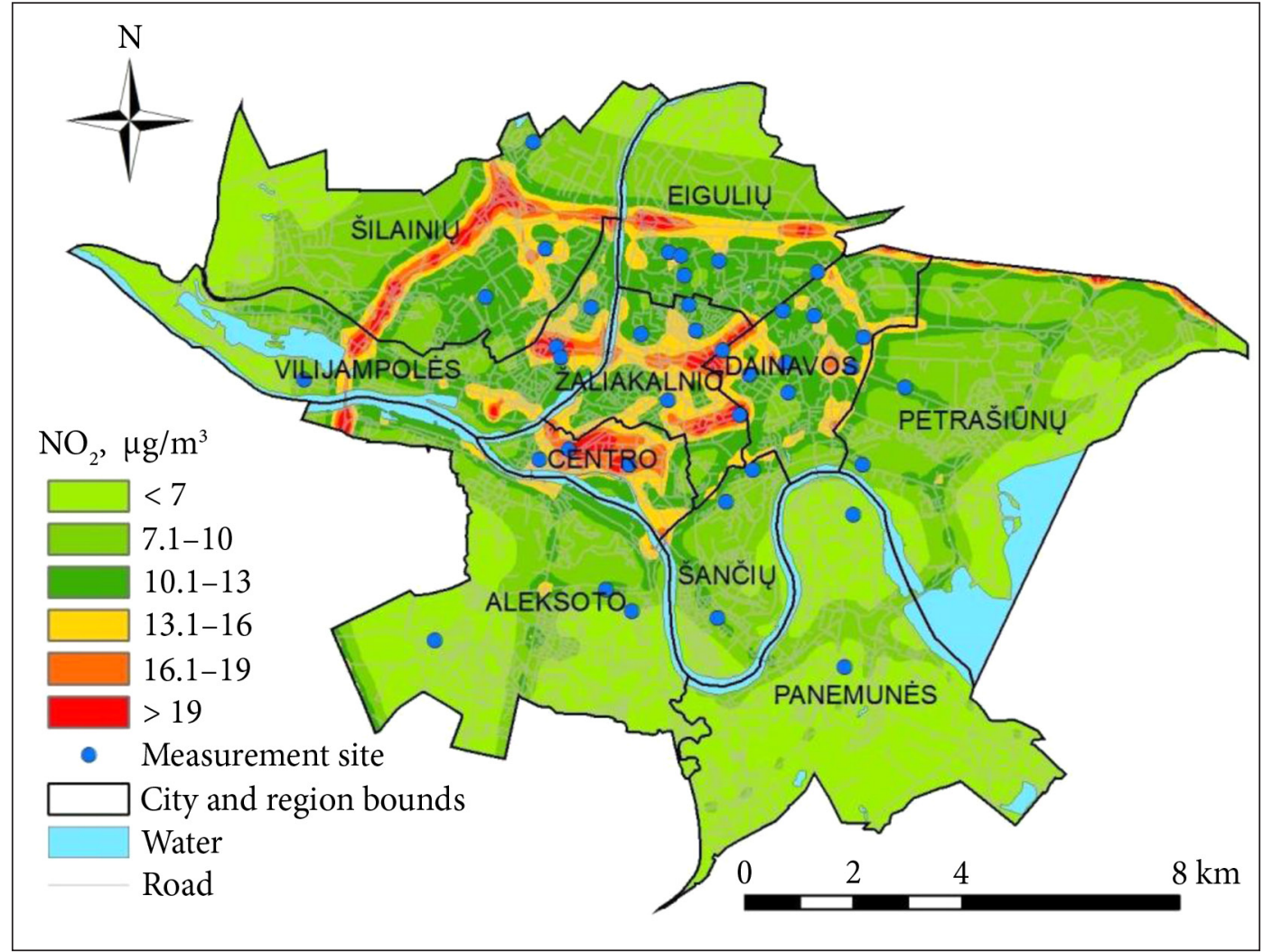

Fig. 3. Modelled nitrogen dioxide concentration $\left(\mu \mathrm{g} / \mathrm{m}^{3}\right)$ in warm season and passive samplers measurements sites in Kaunas city

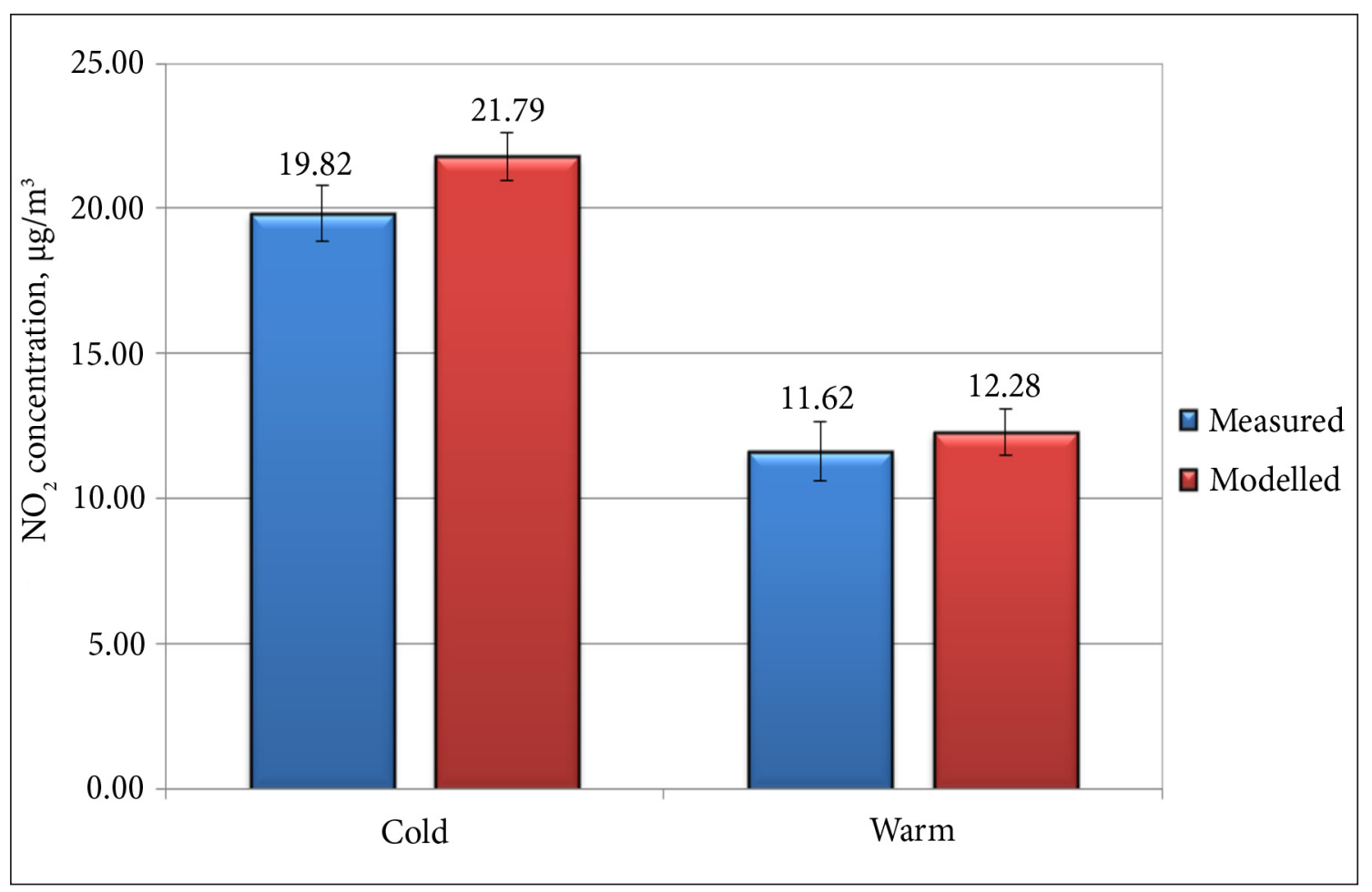

Fig. 4. $\mathrm{NO}_{2}$ concentrations measured with passive samplers and modelled with ADMS-Urban model in cold and warm seasons 


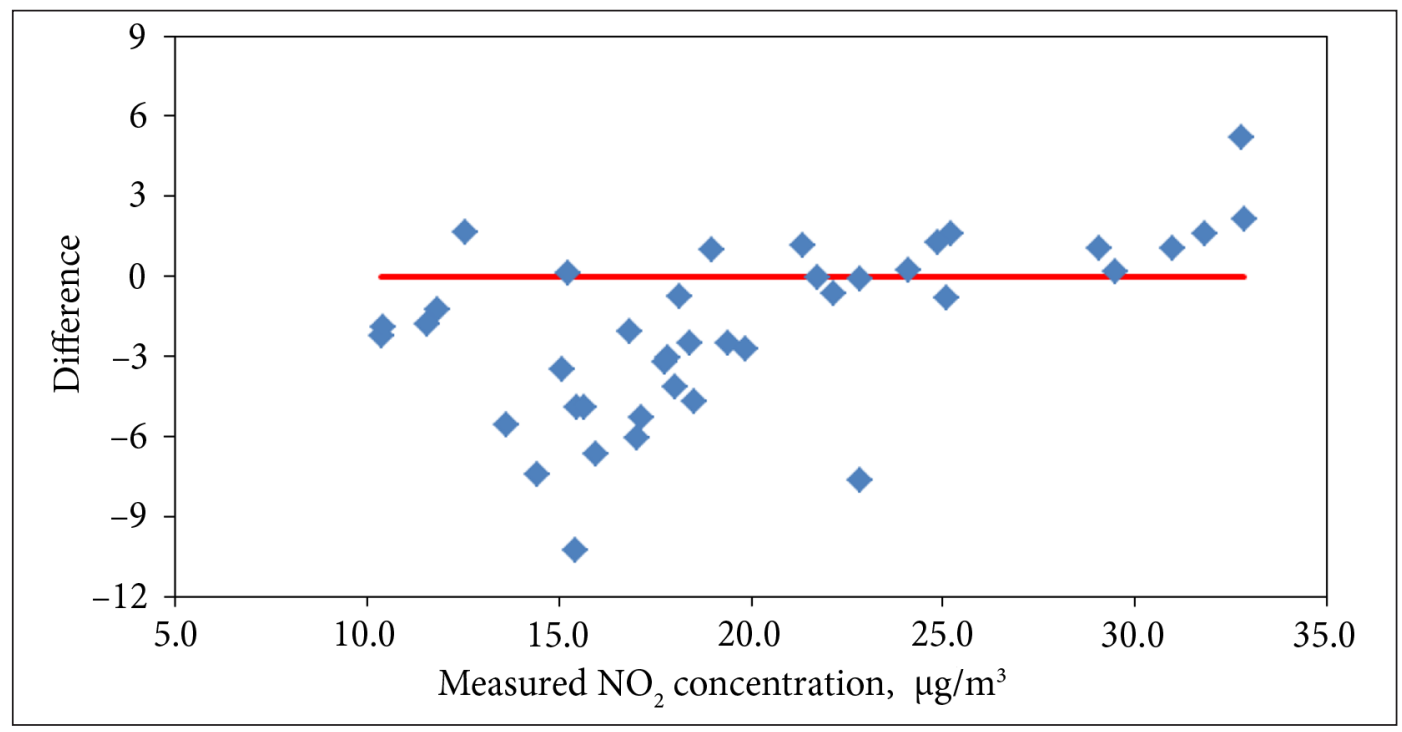

Fig. 5. Difference between concentrations of $\mathrm{NO}_{2}$ measured by Ogawa passive samplers and modelled using ADMS-Urban model in cold season

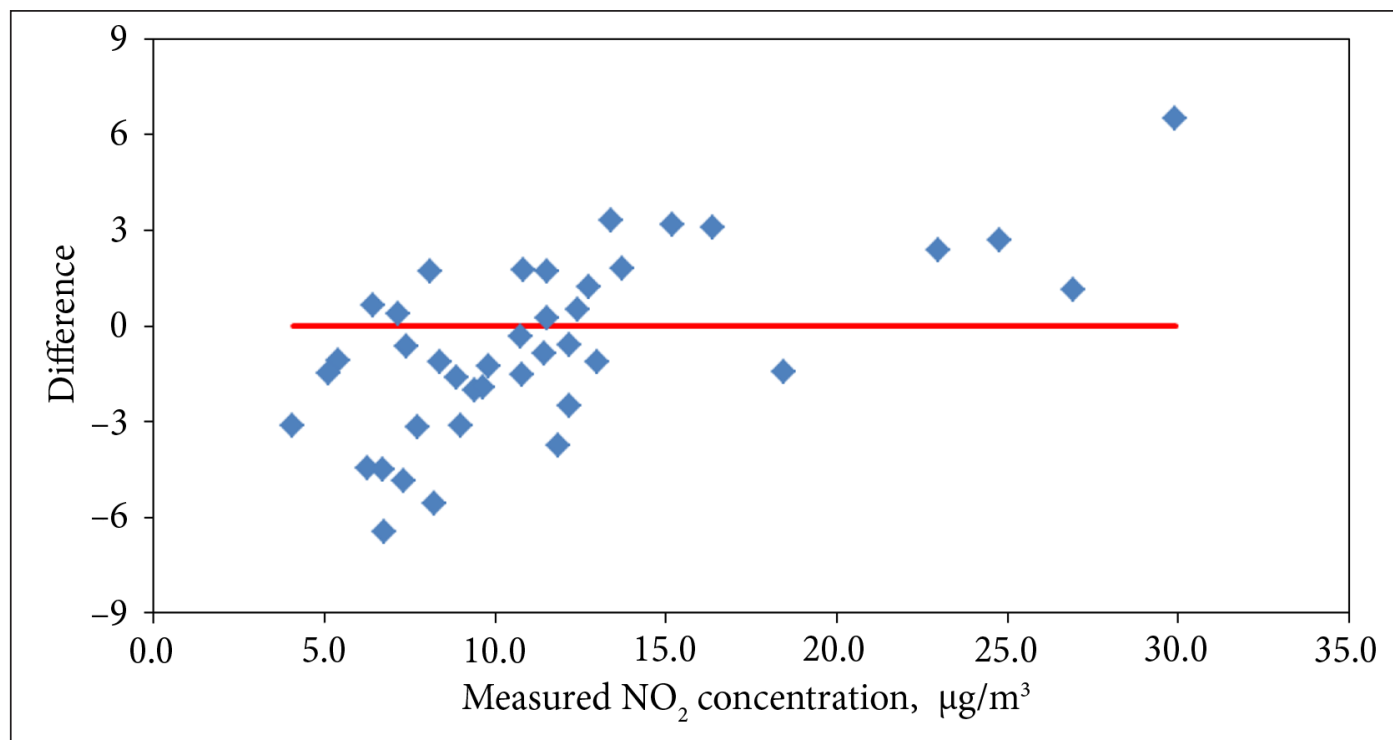

Fig. 6. Difference between concentrations of $\mathrm{NO}_{2}$ measured by Ogawa passive samplers and modelled using ADMS-Urban model in warm season

cold and warm seasons. Similar experiments were carried out in Vilnius city in October-November for 2011. The concentrations measured with diffusive samplers differed by $13.9 \%$ on average from the concentrations modelled with ADMS-Urban (Šerevičienè et al., 2011).

The data presented in Fig. 5 show that during cold season the difference between most of the measured and modelled values ranged from -6 to $2 \mu \mathrm{g} / \mathrm{m}^{3}$, while during the warm season the difference between concentrations of $\mathrm{NO}_{2}$ measured by Ogawa passive samplers and modelled using ADMS-Urban model were lower and most values ranged from -2 to 2 $\mu \mathrm{g} / \mathrm{m}^{3}$ (Fig. 6).

The results showed that ADMS-Urban dispersion model tends to overpredict nitrogen dioxide concentrations and this is most 
evident when smaller values are modelled, while modelled maximum concentrations are underestimated compared with measured $\mathrm{NO}_{2}$ values. The uncertainties of characterizing sources of emissions, physical / chemical processes, monitoring or background concentrations may have led to an underestimation or overestimation of modelled concentrations of nitrogen dioxide compared with measured values (Berkowitz et al., 2006).

\section{CONCLUSIONS}

1. The highest average $\mathrm{NO}_{2}$ concentration was modelled in the central district $-27.4 \mu \mathrm{g} / \mathrm{m}^{3}$ and $18.4 \mu \mathrm{g} / \mathrm{m}^{3}$ in both cold and warm seasons, respectively. The lowest $\mathrm{NO}_{2}$ concentration was in Panemunè district -2.7 and $6.5 \mu \mathrm{g} / \mathrm{m}^{3}$, respectively.

2. Modelled average nitrogen dioxide concentration in Kaunas city was $21.79 \mu \mathrm{g} / \mathrm{m}^{3}$ in cold season and $12.28 \mu \mathrm{g} / \mathrm{m}^{3}$ in warm season.

3. The difference between modelled and measured $\mathrm{NO}_{2}$ concentrations was $9.9 \%$ and $5.7 \%$, respectively in cold and warm seasons.

Received 27 May 2013

Accepted 09 November 2013

\section{References}

1. Ballester F, Tenias J, Perez-Hoyos S. Air pollution and emergency hospital admissions for cardiovascular diseases in Valencia, Spain. J Epidemiol Comm Health 2001; 55(1): 57-65.

2. Bellander $\mathrm{T}$, Berglind $\mathrm{N}$, Gustavsson $\mathrm{P}$, Jonson T, Nyberg F, Pershagen G, Järup L. Using geographic information systems to assess individual historical exposure to air pollution from traffic and house heating in Stockholm. Environ Health Persp 2001, 109(6): 633-639.

3. Berkowitz R, Winther M, Ketzel M. Traffic pollution modeling and emission data. Environ Model Software 2006; 21: 454-460.
4. Bogo H, Gomez DR, Reich SL, Negri RM, San Roman E. Traffic pollution in a downtown site of Buenos Aires City. Atmosph Environ 2001; 35(10): 1717-1727.

5. CERC. ADMS-Urban User Guide. 2011. [http://www.cerc.co.uk/environmental-software/assets/data/doc_userguides/CERC_ ADMS-Urban3.1_User_Guide.pdf].

6. Colvile RN, Hutchinson EJ, Mindell JS, Warren RA. The transport sector as a source of air pollution. Atmosph Environ 2001; 35: 15371565.

7. Daly A, Zannetti P. Ambient Air Pollution. Air Pollution Modeling - An Overview, Chapter 2 of Ambient air pollution. The Arab School for Science and Technology (ASST) and The EnviroComp Institute 2007; 15-28.

8. EEA. Air quality in Europe - 2012 report. European Environment Agency 2012; 106.

9. Jakimavičius M, Burinskienė M. A GIS and multi-criteria-based analysis and ranking of transportation zones of Vilnius city. Technol Econ Develop Econ 2009; 15(1): 39-48.

10. Lee JT, Kim H, Song H, Hong YC, Cho YS, Shin SY, Hyun YJ, Kim YS. Air pollution and asthma among children in Seoul, Korea. Epidem 2002; 13(4): 481-484.

11. Owen B, Edmunds HA, Carruthers DJ, Raper DW. Use of a new generation urban scale dispersion model to estimate the concentration of oxides of nitrogen and sulphur dioxide in a large urban area. The Sci Total Environ 1999; 235(1): 277-291.

12. Silva LT, Mendes JFG, Ramos RAR. Validation Study of Urban Air Dispersion Model of Viana Do Castelo. 2nd International Conference on Waste Management, Water Pollution, Air Pollution, Indoor Climate (WWAI'08), Corfu, Greece 2008; 194-199.

13. Studnicka M, Hackl E, Pischinger J, Fangmeyer C, Haschke N, Kühr J, Urbanek R, Neumann M, Frischer T. Traffic-related $\mathrm{NO}_{2}$ and the prevalence of asthma and respiratory symptoms in seven year olds. Eur Respir J 1997; 10: 2275-2278. 
14. Šerevičienè V, Paliulis D. Assessment of air quality using diffusive samplers and ADMSUrban. Ekologija 2011; 57(3): 129-136.

15. Zuurbier M, Hoek G, Oldenwening $M$, Meliefste K, Van den Hazel P, Brunekreef B. Respiratory effects of commuters' exposure to air pollution in traffic. Epidem 2011; 22(2): 219-227.

\section{Audrius Dẻdelè, Auksẻ Miškinytė}

\section{ADMS-URBAN MODELIAVIMO \\ PROGRAMOS TAIKYMAS AZOTO \\ DIOKSIDO KONCENTRACIJAI ŠALTUOJU \\ IR ŠILTUOJU SEZONAIS KAUNO MIESTE NUSTATYTI}

\section{Santrauka}

Kelių transportas yra vienas pagrindinių taršos šaltinių, turintis itakos miestų oro kokybei ir gyventojų sveikatai. Azoto dioksidas $\left(\mathrm{NO}_{2}\right)$ yra vienas labiausiai paplitusių transporto sąlygojamų teršalų. ADMS-Urban modeliavimo programa gali ịvertinti daugelio ịvairių šaltinių (kelių transporto, pramonès, individualių gyvenamụjų namų) išmetamų teršalų sklaidą ir nustatyti ar numatyti teršalų koncentracijas atmosferoje iš šių taršos šaltinių.
Azoto dioksido koncentracijai prognozuoti naudojama ADMS-Urban modeliavimo programa. Sumodeliuota šaltojo ir šiltojo sezonų azoto dioksido koncentracija buvo palyginta su išmatuota $41 \mathrm{Kau}-$ no miesto vietoje. Šio tyrimo tikslas buvo ịvertinti azoto dioksido taršos sklaidą šaltuoju ir šiltuoju sezonais bei nustatyti skirtumus tarp išmatuotos su pasyviais kaupikliais ir ADMS-Urban modeliavimo programa sumodeliuotos $\mathrm{NO}_{2}$ koncentracijos Kauno mieste.

Šaltuoju sezonu sumodeliuota azoto dioksido koncentracija buvo $21,79 \mu \mathrm{g} / \mathrm{m}^{3}$, o pasyviais kaupikliais išmatuota - $19,82 \mu \mathrm{g} / \mathrm{m}^{3}$. Šiltuoju sezonu sumodeliuota ir išmatuota koncentracija atitinkamai buvo 12,28 ir $11,62 \mu \mathrm{g} / \mathrm{m}^{3}$. Taigi oro tarša buvo reikšmingai didesnè šaltuoju sezonu. Rezultatai rodo, kad ADMS-Urban modeliavimo programa sumodeliuoja didesnes azoto dioksido koncentracijas, palyginti su išmatuotomis, ir tai labiausiai akivaizdu, kai modeliuojamos mažesnès vertès, o sumodeliuotos maksimalios $\mathrm{NO}_{2}$ koncentracijos yra gaunamos mažesnès nei išmatuotos su pasyviais kaupikliais.

Raktažodžiai: azoto dioksidas, modeliavimas, ADMS-Urban modeliavimo programa, žmonių sveikata 